Iosr Journal Of Pharmacy

E-Issn: 2250-3013, P-Issn: 2319-4219 Www.Iosrphr.Org

Volume 3, Issue 1 (February 2013), Pp 04-09

\title{
Cardiotonic Activity of Alcoholic Bark Extract of Xylocarpus Granatum with Emphasis on Its Mechanism of Action
}

\author{
${ }^{1}$ Y. Trilochana, ${ }^{2}$ P. Sowjanya, ${ }^{3}$ G.P.V. Sangeetha, ${ }^{4}$ P. Rajeswara Rao, ${ }^{5}$ Prof. P. \\ Rajeswara Rao \\ 1, 2, 3, 4 Pharmacology Division, A.U. College of Pharmaceutical Sciences, Andhra University, Visakhapatnam- \\ 530 003, Andhra Pradesh, India. \\ ${ }^{5}$ Pharmacology Division Department of Pharmaceutical sciences \\ Andhra University Visakhapatnam- 530003 \\ Andhra Pradesh, India
}

\begin{abstract}
The aim of the present study was to scan and evaluate cardiotonic activity of alcoholic bark extract of Xylocarpus granatum and to establish its mechanism of action. The alcoholic extract of the bark of Xylocarpus granatum was prepared by the process of continuous extraction (soxhlation). The cardiotonic activity of the extract was evaluated on isolated normal and hypodynamic frog heart using Syme's technique. Potassium loss was estimated in the effluents collected from the isolated perfused hypodynamic heart (control and inhibitory activity of the extract was estimated using the same frog heart muscle. The extract showed dose dependent positive ionotropic effect on normal and hypodynamic frog heart, loss of potassium ions and the percentage inhibition of $\mathrm{Na}^{+}, \mathrm{K}^{+}$ATPase activity. The percentage inhibition of $\mathrm{Na}^{+}, \mathrm{K}^{+}$ATPase activity with digoxin at a dose of $300 \mu \mathrm{g}$ was found to be $93.80 \pm 1.98 \%$. Similarly, the extract also showed dose dependent (2, 20, 200 $\mathrm{mg}$ ) percentage inhibition of $\mathrm{Na}^{+}, \mathrm{K}^{+}$ATPase activity and was found to be $35.20 \pm 4.96 \%, 40.10 \pm 1.27 \%, 56.74$ $\pm 3.01 \%$ respectively. Results clearly indicated that the bark extract of Xylocarpus granatum possesses significant cardiotonic activity and follows the similar mechanism of digoxin (inhibition of $\mathrm{Na}^{+}, \mathrm{K}^{+}$ATPase enzyme activity).
\end{abstract}

Keywords: Cardiotonic activity, Frog heart, $\mathrm{Na}^{+}, \mathrm{K}^{+}$ATPase, Xylocarpus granatum.

\section{Introduction}

Nature is an abundant reservoir of medicinal plants gifted by the god which has been the most productive source of leads for the development of drugs ${ }^{[1]}$. This is widely accepted to be true because most of the drugs discovered, starting from miracle drug Aspirin to Digoxin, the only life saving drug molecule available till date to treat congestive heart failure (CHF) were discovered from natural resource ${ }^{[2]}$. Congestive heart failure is a syndrome characterized by persistent inability of the ventricle to eject blood volume associated with deterioration in hemodynamic status and exercise intolerance. The drugs available to treat congestive heart failure are cardiotonic agents like digoxin and digitoxin which pose a great value in treating congestive heart failure but their efficacy remains controversial as their therapeutic margin is narrow $(0.5 \mathrm{ng}$ to $2.5 \mathrm{ng} / \mathrm{ml}$ for digoxin and $10 \mathrm{ng}$ to $35 \mathrm{ng} / \mathrm{ml}$ for digitoxin $)^{[3]}$. If the therapeutic window is low, there is a possibility for showing adverse effects and sometimes, it may be lethal. Other allopathic drugs available for congestive heart failure are diuretics, cardiac stimulants (dopamine, dobutamine), Angiotensin Converting Enzyme Inhibitors (Captopril), Angiotensin receptor blockers (Losartan), Vasodilators and Phosphodiesterase inhibitors but, they are not specific in action and produce adverse effects like dysrhythmias ${ }^{[4]}$. Further, cardiac glycosides toxicity continues to be a main problem due to their narrow therapeutic window, there by leading to deterioration in quality of life and increased incidence of mortality. Thus, there is indispensability for further research in this discipline, to discover potential leads with less toxicity and greater efficacy.Xylocarpus granatum belongs to the family Meliaceae, and commonly known as Cannonball mangrove. Species of Xylocarpus granatum are rich in tannins and flavonoid type ${ }^{[5]}$ of compounds which are known for their medicinal properties and have been traditionally used by people of tropical places like East Asia, Madagascar, Tropical Australia and Polynesia. The astringent bark is used for treating ailments like dysentery, diarrhoea, some abdominal troubles and as a febrifuge ${ }^{[6,7]}$. The oil extracted from the seeds has been used as illuminant and hair oil. The Indians use the fruit to treat swellings of breast and also elephantiasis. Preliminary screening reports on various parts of the plant (leaves, bark, stem and root) were found to possess activities like antimicrobial, antimalarial, antifilarial, antiulcer, antidiarrhoeal, fungicidal, cancer and wound healing ${ }^{[8-15]}$. Keeping in view the limitations of available cardiotonics and folkloric claims on the plant, the present study has been undertaken to scan and evaluate the cardiotonic activity of Xylocarpus granatum. 


\subsection{Plant material}

\section{Materials And Methods}

The Xylocarpus granatum bark was collected from Santhasramam region of Bay of Bengal, Visakhapatnam, Andhra Pradesh, India.

\subsection{Preparation of alcoholic extract}

Freshly collected bark of Xylocarpus granatum was dried under shade and dried material was milled to obtain coarse powder. The alcoholic extract of the powder was prepared by the process of continous extraction (Soxhlation), such that $1 \mathrm{~g}$ of alcoholic extract is equivalent to $2.35 \mathrm{~g}$ of crude drug.

\subsection{Animals}

Adult healthy frogs (Rana tigrina) of either sex weighing 200 to $250 \mathrm{~g}$ were selected. All studies were performed in accordance with Institutional Animal Ethics Committee (IAECNO: 439/PO/01/a/CPCSEA)

\subsection{Experimental protocol}

\subsubsection{Effect of the extract on isolated frog heart}

The frogs were sacrificed by pithing. The heart was isolated briskly and washed with saline, mounted on Syme's cannula using Syme's technique. Normal heart was run with Ringer's solution and hypodynamic heart was developed with half calcium Ringer. The alcoholic extract was made into a solution using $10 \%$ Dimethyl sulfoxide (DMSO) and the final volume was adjusted with saline to obtain various concentrations of the extracts. The extract was administered as spot doses of gradient concentrations into the Syme's cannula. The responses were recorded on Sherrington Kymograph at a speed of $0.12 \mathrm{~mm} / \mathrm{sec}^{[16]}$.

\subsubsection{Estimation of Potassium loss from the isolated frog heart using flame Photometry}

Effluents were collected from the isolated perfused hypodynamic heart (control and treatment groups) for the estimation of potassium ions with the aid of flame photometer (ELICO CL 361) ${ }^{[17]}$.

\subsubsection{Estimation of $\mathrm{Na}^{+}, \mathrm{K}^{+} \mathrm{ATP}$-ase activity on frog heart muscle}

The frog was sacrificed and the heart was isolated rapidly and washed in ice-cold normal saline to remove any clots present. The ventricular portion was excised, minced, homogenized in $20 \mathrm{mM}$ Tris- $\mathrm{HCl}$ buffer at $0^{\circ} \mathrm{C}$ for 5 minutes, filtered and the filtrate was adjusted to contain about $10 \%$ protein by the addition of Tris$\mathrm{HCl}$ buffer ( $\mathrm{pH} \mathrm{7.4)}$ and $0.2 \mathrm{ml}$ aliquots of the whole tissue homogenate was used as source of ATP-ase. ATPase activity was estimated in a reaction mixture of $1 \mathrm{ml}$ containing $140 \mathrm{mM} \mathrm{NaCl}, 14 \mathrm{mM} \mathrm{KCl}, 3 \mathrm{mM}$ EDTA, $20 \mathrm{mM}$ Tris- $\mathrm{HCl}$ buffer and $1 \mathrm{mM}$ EGTA. The solutions of the extracts of Xylocarpus granatum and digoxin were prepared using double distilled water. The enzyme $(0.2 \mathrm{ml}$ aliquots $)$ was pre-incubated in the reaction mixture with $300 \mu \mathrm{g}$ of Digoxin and gradient concentrations of Xylocarpus granatum respectively for 10 minutes at $31 \pm 1^{\circ} \mathrm{C}$. The reaction was initiated by the addition of $0.05 \mathrm{ml}$ of $30 \mathrm{mM} \mathrm{Na}$-ATP solution and maintained at same temperature for 30 minutes with occasional shaking. The reaction was terminated by addition of $1 \mathrm{ml}$ of $10 \%$ Trichloroaceticacid (TCA). The above solution was centrifuged for 15 minutes at 3500 rpm. To $1 \mathrm{ml}$ of supernatant liquid, $5 \mathrm{ml}$ of $10 \%$ TCA, $1 \mathrm{ml}$ of ammonium molybdate solution, $0.4 \mathrm{ml}$ of 1, 2, 5 tri amino nitro sulfonic acid (121 ANSA) reagents were added and the final volume was made up to $10 \mathrm{ml}$ with distilled water. The difference in the specific activities in the presence and absence of Digoxin and extract was considered due to $\left(\mathrm{Na}^{+}, \mathrm{K}^{+}\right)$ATPase ${ }^{[18,19]}$. The specific activities were expressed as n Moles Pi liberated/mg protein/minute. The inorganic phosphates liberated in the reaction were determined by the method of Gomori ${ }^{[20]}$.

\subsection{Statistical analysis}

Results were analyzed by one-way ANOVA using Dunnett's multiple comparison tests using Graph pad Prism 5 software. A probability level of 0.001 or less was accepted as significant.

\section{Results}

In normal and hypodynamic hearts the alcoholic bark extract of Xylocarpus granatum and digoxin produced a dose dependent positive ionotropic effect and an increase in cardiac output (Table1; Fig. 1, 2, 3). The positive ionotropic effect of the extract was not blocked by Timolol. Potassium ions level in freshly prepared half calcium ringer was found to be $20.45 \pm 0.29 \mathrm{ppm}$. In control group (hypodynamic heart), the $\mathrm{K}^{+}$ levels were found to be $15.50 \pm 0.31 \mathrm{ppm}$. The alcoholic bark extract and digoxin showed a dose dependent increase in $\mathrm{K}^{+}$ion levels in the effluents (Table 2). The percentage inhibition of $\mathrm{Na}^{+}, \mathrm{K}^{+}$ATPase in digoxin (300 $\mu \mathrm{g})$ and extract $(200 \mathrm{mg})$ treated groups was found to be $93.80 \pm 1.98 \%$ and $56.74 \pm 3.01 \%$ respectively (Table 3; Fig. 4). 


\section{Discussion}

Cardiac activity is regulated by many mechanisms to meet the need of the circulation rate from time to time through Autonomic nervous system (ANS), renin-angiotensin system (RAS) and baroreceptors. In congestive heart failure, the defect lies in contraction coupling element due to $\mathrm{Ca}^{2+}$ insufficiency or improper utilization of $\mathrm{Ca}^{2+}$ by the cell. At this juncture, drugs which increase the intracellular $\mathrm{Ca}^{2+}$ will show beneficial effects. The positive ionotropic action of various drugs may be through direct stimulation of adrenergic receptors or indirect sympathomimetic action, inhibiting the phosphodiesterase III or direct action on the cardiac muscle ${ }^{[21]}$ through $\mathrm{Na}^{+}, \mathrm{K}^{+}$ATPase inhibition. In the present study, the alcoholic extract of Xylocarpus granatum produced a dose dependent positive ionotropic effect on isolated frog heart in normal and hypodynamic conditions. The positive ionotropic effect produced by the extract may be through cardiac stimulation or by increasing the availability of intracellular $\mathrm{Ca}^{2+}$ in myocytes or by varied mechanisms. The results with Timolol, a $\beta$-receptor antagonist, ruled out the involvement of $\beta$ receptors by showing inability in inhibiting the positive ionotropic effect produced by the alcoholic extract of Xylocarpus granatum. It is reported that Digoxin increases $\mathrm{K}^{+}$levels in the effluent due to the inhibition of $\mathrm{Na}^{+}, \mathrm{K}^{+}$ATPase pump ${ }^{[22]}$. It is observed that the bark extract of Xylocarpus granatum also increased the $\mathrm{K}^{+}$levels in the effluent in a dose dependent manner. This supports that the possible mechanism of the extract may be through inhibition of $\mathrm{Na}^{+}, \mathrm{K}^{+}$ATPase pump. Further studies on $\mathrm{Na}^{+}, \mathrm{K}^{+}$ATPase inhibitory activity revealed that the positive ionotropic effect produced by the extract is through the inhibiton of $\mathrm{Na}^{+}, \mathrm{K}^{+}$ATPase pump as it is evidenced by the reduction in the release of inorganic phosphates from ATP. Overall, the present study clearly indicates that the positive ionotropic effects produced by the extract may be due to inhibition of $\mathrm{Na}^{+}, \mathrm{K}^{+}$ATPase pump which simulates the action of digoxin.

\section{Conclusions}

The current study reveals that the alcoholic bark extract of Xylocarpus granatum possesses good cardiotonic activity and its possible mechanism may be through inhibition of $\mathrm{Na}^{+}, \mathrm{K}^{+}$ATPase pump. Further studies on bioassay guided fractionation and purification may yield the bio-active molecules responsible.

\section{Acknowledgements}

The authors are grateful to acknowledge Management of Andhra University for the facilities provided by them to carry out this work.

\section{References}

[1] SM Rates, Plants as source of drugs, Toxicon, 39, 2001, 603-613

[2] JG Patil, ML Ahire, KM Nitnaware, S Panda, VP Bhatt, and PB Kishor, et al. In vitro propagation and production of cardiotonic glycosides in shoot cultures of Digitalis purpurea L. by elicitation and precursor feeding, Appl Microbiol Biotechnol, 2012. [printing]

[3] M Packer, The search for the ideal positive inotropic agent, $N$ Engl Med, 329, 1993, 201-202.

[4] H Luellmann, K Mohr, A Ziegler, and D Bieger, Color Atlas of Pharmacology (Thieme Stuttgart: New York, 2000).

[5] F Cheng, Y Zhou, K Zou, and J Wu, Studies on the chemical constituents of the fruit of Xylocarpus granatum, Zhong Yao Cai, 32(8), 2009, 1220-1223.

[6] A Ghani, Medicinal Plant of Bangladesh with Chemical Constituents and Uses (Asiat Soc Bangladesh, 1998).

[7] K.R. Kirtikar, and B.D. Basu. Indian Medicinal Plants. (International Book Distributors: India, 1996).

[8] P Rajeshwara Rao, Y Trilochana, and KK Chaitanya, Anti-diarrhoeal and antimicrobial activities of bark and leaf extracts of Xylocarpus granatum Koenig, J Nat Rem, 3(2), 2003, 155-160.

[9] MA Alam, M Sarder, MA Awal, MMH Sikder, and KA Daulla. Antibacterial activity of the crude ethanolic extract of Xylocarpus granatum stem barks, Bangl J Vet Med, 4(1), 2006, 69-72.

[10] R Rouf, SJ Uddin, JA Shilpi, and M Alamgir. Assessment of antidiarrhoeal activity of the methanol extract of Xylocarpus granatum bark in mice model, J Ethnopharmacol, 109(3), 2007, 539-542.

[11] SJ Uddin, L Nahar, JA Shilpi, M Shoeb, T Borkowski, S Gibbons, M Middleton, M Byres, and SD Sarker. Gedunin, a limonoid from Xylocarpus granatum, inhibits the growth of CaCo-2 colon cancer cell line in vitro, Phytother Res, $21(8), 2007,757-761$.

[12] S Du, M Wang, W Zhu, and Z Qin, A new fungicidal lactone from Xylocarpus granatum (Meliaceae), Nat Prod Res, 23(14), 2009, 1316-1321.

[13] V Lakshmi, S Srivastava, SK Mishra, MN Srivastava, K Srivastava, and SK Puri. Antimalarial activity in Xylocarpus granatum (Koen), Nat Prod Res, 26(11), 2012, 1012-1015.

[14] S Misra, M Verma, SK Mishra, S Srivastava, V Lakshmi, and S Misra-Bhattacharya. Gedunin and photogedunin of Xylocarpus granatum possess antifilarial activity against human lymphatic filarial parasite Brugia malayi in experimental rodent host, Parasitol Res, 109(5), 2011, 1351-1360.

[15] V Lakshmi, N Singh, S Shrivastva, SK Mishra, P Dharmani, and V Mishra, et al. Gedunin and photogedunin of Xylocarpus granatum show significant anti secretary effects and protect the gastric mucosa of peptic ulcer in rats, Phytomedicine, 17(8-9), 2010, 569-574.

[16] J.H. Burn. Practical pharmacology (Blackwell scientific publications: Oxford, 1952).

[17] H Gerhard Vogel. Potassium loss from the isolated guinea pig heart, Drug Discovery and Evaluation Pharmacological Assays (New York: Springer-Verlag Berlin Heildberg, 2002).

[18] MA Azeem, B Madhva reddy, AVN Appa rao, and MC Prabhakar. Effect of Terminalia chebula extracts on frog heart muscle $\left(\mathrm{Na}^{+}, \mathrm{K}^{+}, \mathrm{Mg}^{++}\right)$ATP-ase activity, Fitoterapia, 63, 1992, 300-303.

[19] N Raghu Ramulu, K Madhavan Nair, and S Kalyana Sundaram. A Manual of Laboratory Techniques (National Institute of Nutrition: India, 2003). 
[20] G Gomori, A modification of the colorimetric phosphorus determination for use with a photoelectric colorimeter, $J$ Lab Clin Med, 27, 1942, 955-957.

[21] BH Vasavada, AA Mehta, DD Santani, and RK Goyal, Mechanism of action of various inotropic agents: A search for a digitals [sic] substitute, Indian J Pharmacol, 22, 1990, 119-127.

[22] E Lindner, and P Hajdu, Die fortlaufende Messung des Kaliumverlustes des isolierten Herzens zur Bestimmung der Wirkungsstärke digitalisartiger Körper, Arch Int Pharmacodyn, 175, 1968, 365-372.

Table 1: Effect of Xylocarpus granatum \& Digoxin on isolated normal and hypodynamic frog heart.

\begin{tabular}{|c|c|c|c|c|c|c|c|c|}
\hline \multirow[t]{2}{*}{ Sampl } & \multicolumn{2}{|c|}{$\begin{array}{l}\text { Force of Contraction } \\
\quad(\text { height in } \mathrm{cm})\end{array}$} & \multicolumn{2}{|c|}{$\begin{array}{c}\text { Change in } \\
\text { response } \\
(\text { height in } \mathrm{cm})\end{array}$} & \multicolumn{2}{|c|}{$\begin{array}{c}\% \text { increase in } \\
\text { response } \\
\text { (height })\end{array}$} & \multicolumn{2}{|c|}{$\begin{array}{l}\% \text { increase in } \\
\text { cardiac output }\end{array}$} \\
\hline & $\begin{array}{l}\text { Normal } \\
\text { Ringer }\end{array}$ & $\begin{array}{l}1 / 2 \mathrm{Ca}^{2+} \\
\text { Ringer }\end{array}$ & $\begin{array}{l}\text { Normal } \\
\text { Ringer }\end{array}$ & $\begin{array}{l}1 / 2 \mathbf{C a}^{2+} \\
\text { Ringer }\end{array}$ & $\begin{array}{l}\text { Normal } \\
\text { Ringer }\end{array}$ & $\begin{array}{l}1 / 2 \mathbf{C a}^{2+} \\
\text { Ringer }\end{array}$ & $\begin{array}{l}\text { Normal } \\
\text { Ringer }\end{array}$ & $\begin{array}{l}1 / 2 \mathbf{C a}^{2+} \\
\text { Ringer }\end{array}$ \\
\hline Control & 1.3 & 0.8 & - & - & - & - & - & - \\
\hline X. g E $1 \mathrm{mg}$ & 1.4 & 1.1 & 0.1 & 0.3 & - & $30 \%$ & - & - \\
\hline X. g E $2 \mathrm{mg}$ & 1.4 & $1.2^{*}$ & 0.1 & 0.4 & $10 \%$ & $40 \%$ & $10 \%$ & $5 \%$ \\
\hline X. g E $3 \mathrm{mg}$ & $1.7^{*}$ & $1.2^{*}$ & 0.4 & 0.4 & $40 \%$ & $40 \%$ & $15 \%$ & $5 \%$ \\
\hline X.g E $10 \mathrm{mg}$ & $2.4^{*}$ & $1.3^{*}$ & 1.1 & 0.5 & $110 \%$ & $50 \%$ & $20 \%$ & $10 \%$ \\
\hline X. g E $20 \mathrm{mg}$ & $2.5^{*}$ & $2.0^{*}$ & 1.2 & 1.2 & $120 \%$ & $120 \%$ & $25 \%$ & $15 \%$ \\
\hline Digoxin $50 \mu \mathrm{g}$ & - & 1.0 & - & 0.2 & - & $20 \%$ & - & - \\
\hline Digoxin $150 \mu \mathrm{g}$ & - & 1.1 & - & 0.3 & - & $30 \%$ & - & $10 \%$ \\
\hline Digoxin $250 \mu \mathrm{g}$ & - & $1.6^{*}$ & - & 0.6 & - & $60 \%$ & - & $15 \%$ \\
\hline
\end{tabular}

Values are mean \pm SEM of 3 Experiments, *p $<0.001$ compared with control.

X. g E: Xylocarpus granatum extract

Table 2: Estimation of Potassium ions (ppm) in effluent fluids of normal and hypodynamic frog heart treated with alcoholic extract and digoxin.

\begin{tabular}{lcc}
\hline Sample & Normal Ringer (ppm) & Half calcium Ringer (ppm) \\
Ringer & $20.65 \pm 0.18$ & $20.45 \pm 0.29$ \\
Control (normal) & $17.02 \pm 0.31$ & $15.50 \pm 0.31$ \\
Alcoholic extract of & $17.05^{*} \pm 0.35$ & $17.08^{*} \pm 0.33$ \\
$X$. granatum $1 \mathrm{mg}$ & & $22.70^{*} \pm 0.24$ \\
Alcoholic extract of & $18.33^{*} \pm 0.53$ & \\
$X$. granatum $2 \mathrm{mg}$ & & $25.55^{*} \pm 0.46$ \\
Alcoholic extract of & $20.13^{*} \pm 0.19$ & \\
$X$. granatum $3 \mathrm{mg}$ & & $30.48^{*} \pm 0.35$ \\
Alcoholic extract of $X$. granatum & $25.28^{*} \pm 0.69$ & \\
10 mg & & $35.85^{*} \pm 0.68$ \\
Alcoholic extract of $X$. granatum & $31.43^{*} \pm 0.34$ & $21.35^{*} \pm 0.41$ \\
20 mg & - & $32.70^{*} \pm 0.87$ \\
Digoxin $50 \mu \mathrm{g}$ & - & $40.15^{*} \pm 0.62$ \\
Digoxin $150 \mu \mathrm{g}$ & - & \\
Digoxin $250 \mu \mathrm{g}$ & & \\
\hline
\end{tabular}

Values are mean \pm SEM of 3 Experiments, ${ }^{*} \mathrm{p}<0.001$ compared with control. 
Table 3: $\mathrm{Na}^{+}, \mathrm{K}^{+}$ATPase inhibitory activity of alcoholic bark extract of Xylocarpus granatum using frog heart muscle

\begin{tabular}{lcc}
\hline Treatment/dose & $\begin{array}{c}\text { Inorganic phosphates } \\
\text { (n moles/ } \mathbf{~ m g ~ o f ~ t i s s u e / m i n u t e ) ~}\end{array}$ & \% inhibition of $\mathbf{~ a}^{+}, \mathbf{K}^{+} \mathbf{A T P}$ ase \\
\hline & $12.0 \pm 0.15$ & ---- \\
Control & $0.74^{*} \pm 023$ & $93.80 \pm 1.98$ \\
Digoxin $300 \mu \mathrm{g}$ & $7.76^{*} \pm 0.50$ & $35.20 \pm 4.96$ \\
$\begin{array}{l}\text { Alcoholic extract of } X . \\
\text { granatum } 2 \mathrm{mg}\end{array}$ & $7.18^{*} \pm 0.06$ & $40.10 \pm 1.27$ \\
$\begin{array}{l}\text { Alcoholic extract of } X . \\
\text { granatum } 20 \mathrm{mg}\end{array}$ & $56.74 \pm 3.01$ \\
$\begin{array}{l}\text { Alcoholic extract of } X . \\
\text { granatum } 200 \mathrm{mg}\end{array}$ & $5.18^{*} \pm 0.32$ & \\
\hline
\end{tabular}

Values are mean \pm SEM of 3 Experiments, ${ }^{*} \mathrm{p}<0.001$ compared with control.

Fig. 1: Effect of alcoholic bark extract of Xylocarpus granatum on isolated normal frog heart

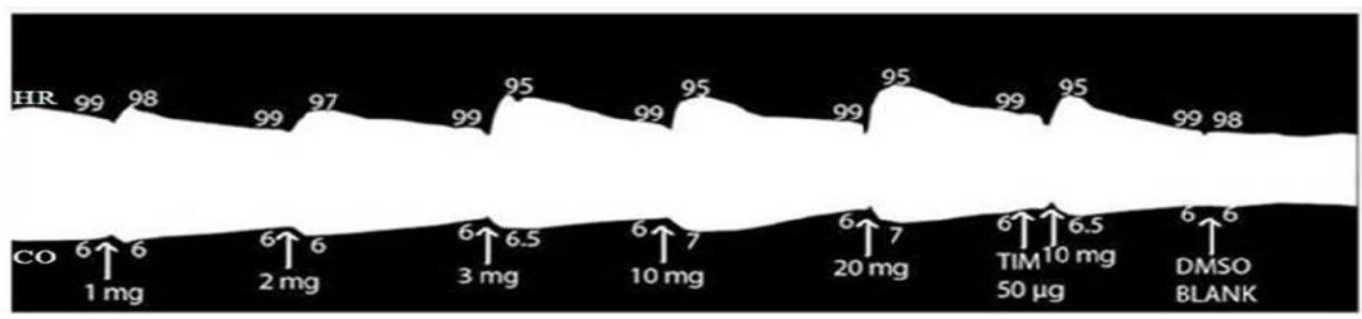

HR: Heart rate; CO: Cardiac output; Tim: Timolol

Fig. 2: Effect of alcoholic bark extract of Xylocarpus granatum on isolated hypodynamic frog heart

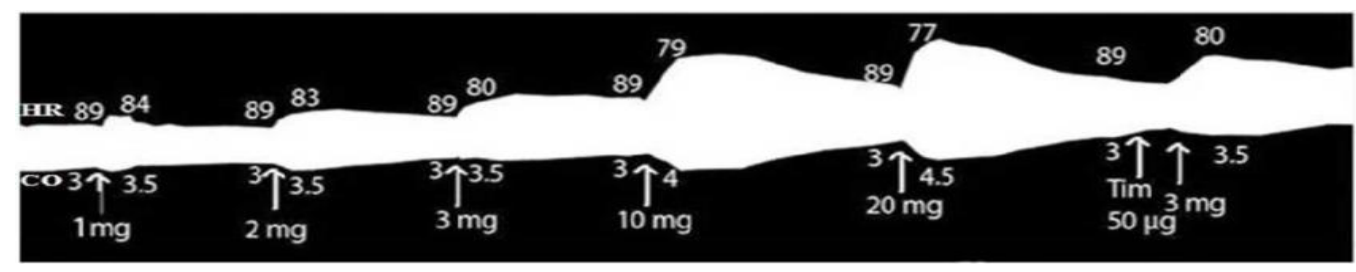

HR: Heart rate; CO: Cardiac output

Fig. 3: Effect of Digoxin on isolated hypodynamic frog heart

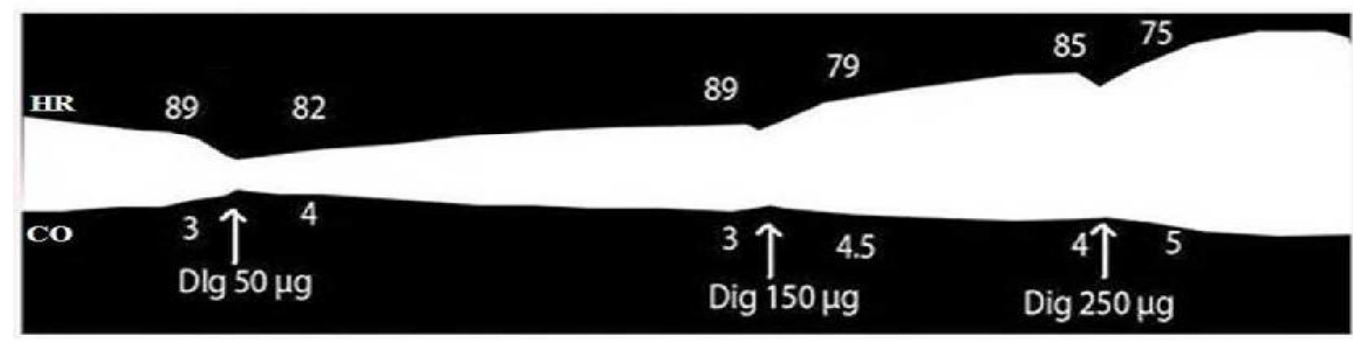

HR: Heart rate; CO: Cardiac output 
Fig. 4: \% Inhibition of $\mathrm{Na}^{+}, \mathrm{K}^{+}$ATPase inhibitory activity of alcoholic extract of Xylocarpus granatum using frog heart muscle.

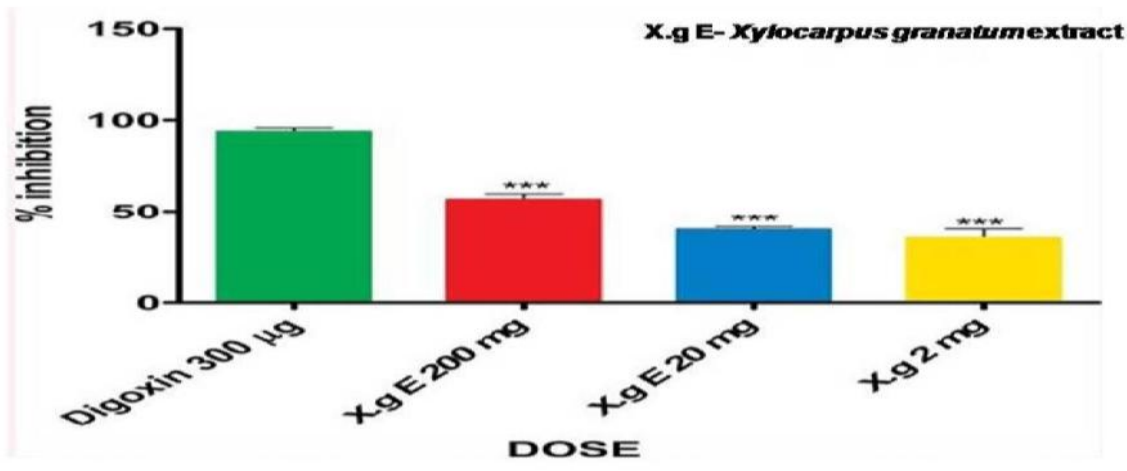

Results were expressed as mean \pm SEM of 3 experiments.

$* * * \mathrm{p}<0.001$, compared with Digoxin. 